An-Nadwah, Vol. XXVI, No.1, Januari-Juni 2020

\title{
STRATEGI KOMUNIKASI PELAKU BISNIS ELECTRONIC COMMERCE (E- COMMERCE) DI MASA PANDEMI COVID-19

\author{
STUDI KASUS MITRA TOKOPEDIA DI MEDAN
}

Oleh : Etikasari, M.S.i

\author{
Dosen STAI Tebing Tinggi Deli \\ Etikasari2108@gmail.com
}

\begin{abstract}
ABSTRAK
Perkembangan teknologi membawa perubahan lingkungan yang kemudian menjadi masalah saat ini menimbulkan kekhawatiran berkepanjangan bagi para pelaku bisnis. Pemasar yang mencoba mempertahankan bisnis mereka pada masa pandemi mengalihkan penjualan dari metode langsung ke sistem pemasaran daring. Sehingga penulis melakukan penelitian ini bertujuan untuk mengetahui masalah yang mendasar di antaranya adalah: Bagaimana Strategi Komunikasi pelaku bisnis Electronic Commerce (Mitra Tokopedia) dalam pemulihan Ekonomi di masa pandemi Covid 19?, Bagaimana Tantangan Strategi Komunikasi pelaku bisnis Electronic Commerce (Mitra Tokopedia) dalam menarik konsumen di masa pandemi Covid-19?, Adapun metode yang di gunakann adalah pendekatan kualitatif dengan teknik pengumpulan data melalui wawancara, observasi dan dokumentasi. Strategi komunikasi pelaku bisnis Electronic Commerce (Mitra Tokopedia) dalam pemulihan Ekonomi di masa pandemi Covid 19 sesuai dengan macam strategi komunikasi yang mana para pelaku bisnis telah menguasai segmen pasar yaitu mampu melihat peluang dan kebutuhan pasar yang di butuhkan saat masa pandemi. Tantangan pelaku bisnis Electronic Commerce (Mitra Tokopedia) dalam menarik konsumen di masa pandemi Covid-19 yaitu persaingan antara para mitra tokopedia yang menjual produk sama namun perbandingan harga yang berbeda, harus mampu aktif dalam mengenalkan tokonya karena hal ini sangat mempengaruhi rating pada toko, semakin sering live akan mengajak para konsumen untuk berkunjung dan belanja. Adapun hambaatan lain secara teknisi adalah jaringan yang eror, respon yang lambat antara kedua bela pihak maupun terdapat barang habis di tokonya. Dalam konsep komunikasi Islam segala sesuatu interaksi sesama manusia pada dasarnya dibolehkan, sejauh tidak ada dalil yang menentukan keharamannya
\end{abstract}

Kata Kunci: Strategi, Pelaku Binis, Tokopedia,Komunikasi Islam 


\section{PENDAHULUAN}

\section{A. Latar Belakang Masalah}

Indonesia adalah ekonomi terbesar di Asia Tenggara. Indonesia memiliki potensi ekonomi yang tinggi, potensi yang mulai di perhatikan dunia Internasional dan memiliki karakteristik yang menempatkan negara Indonesia dalam posisi yang bagus untuk mengalami perkembangan yang pesat. Badan Pusat Statistik (BPS) merilis data pertumbuhan ekonomi Indonesia di sepanjang tahun 2019 di angka 5,7 \%. Namun data terbaru BPS mencatat pertumbuhan ekonomi Indonesia pada kuartal 2020 sebesar 2,97\% year on year (yoy) Pertumbuhan tersebut mengalami kontraksi 2,41\% di bandingkan triwulan IV 2019. Pertumbuhan ekonomi triwulan I 2020 ini, lebih rendah dari kuartal I 2019 yang 5,07\% yoy dan lebih kuartal IV 2019 yang tercatat 4,97\% yoy. ${ }^{1}$

Hal ini mengalami perlambatan yang cukup, dibandingkan periode yang sama tahun lalu, maupun secara kuartal per kuartal dari kuartal terakhir 2019. ${ }^{2}$ Penurunan pertumbuhan ekonomi ini di sebabkan turunya sejumlah ekspor Indonesia salah satunya ke china dan Amerika Serikat dua Negara tujuan ekspor terbesar Indonesia. Sejalan dengan turunya ekspor di beberapa Negara di pengaruhi oleh dampak pendemi covid-19 yang telah menyebar di berbagai Negara awal 2020. Organisasi Kesehatan Dunia (WHO) melansir 216 negara terdampak pandemi covid 19, dengan 15.012.731 jiwa postitif virus corona-19 dan meninggal 619.150 jiwa meninggal. Di Indonesia 93.657 jiwa positif virus covid-19 dan 4.576 jiwa meninggal dunia sedangkan yang sembuh mencapai 52.164 jiwa. ${ }^{3}$ Sehingga sejumlah Negara melakukan lockdown hingga perdagangan ekspor impor terdampak luas.

Covid-19 (Coronavirus disease-2019) adalah salah satu penyakitdari satu jenis virus korona yang bernama SARS-CoV-2 yang muncul di pasar makanan laut Hunan,Wuhan, CIna Desember 2019. Di prediksikan vaksin dapat diproduksi lebih setahun. Kompleksitas permasalahan tetap tak terselesaikan segera sebab akan muncul lagi permasalahan lain seperti keterbatasan vaksin dan pembuatan vaksin antara negara maju dan negara berkembang, serta penentuan paling siapa-siapa yang paling utama membutuhkan.

Pada 11 Maret 2020 WHO mengumumkan Covid-19 sebagai pandemik, yakni wabah yang mengglobal. Menurut WHO kasus Covid-19 ini adalah yang pertama kalinya diumumkan sebagai pandemic serta belum ada yang bisa mengatasinya. WHO dan para ahli sains menyarankan langka dasar aman dari Covid-19: Pertama, social distancing/physical distancing (satu meter berbicara dengan lain). Kedua cuci tangan sesering mungkin, karena virus dapat hinggap pada apapun yang kita sentuh. Ketiga, menghindari menyentuh mata, hidung, dan mulut, sebab hal tersebut tempat masuk virus

${ }^{1}$ https://www.bps.go.id/pressrelease/2020/05/05/1736/ekonomi-indonesia-triwulan-i-2020tumbuh-2-97-persen.html. Diambil pada tanggal 26-Juli-2020,pukul 05-30 WIB.

${ }^{2}$ Menurut Raden, Indikator pendapatan masyarakat menurun disebabkan penurunan perdagangan industri ritel, penurunan produksi usaha, penurunan nilai tukar petan dan penurunan pendapatan pekerja. Sehingga penurunan daya beli masyarakat saat ini sejalan dengan laju inflasi saat ini yang rendah bahkan terkonraksi 0,1 persen pada juli 2020. Dengan kondisi demikian, deflasi harga tidak mengalami kenaikan karena sepi peminat.

${ }^{3}$ https://covid19.go.id/, diambil pada tanggal 25 Juli 2020, pukul 10.20 WIB 
ke dalam bagian lemah kita, khususnya paru-paru yang membuat kita sesak napas. Keempat, menutup hidung dan mulut kita dengan masker yang sesuai standar.

Data Covid-19 dari seluruh kasus di dunia yang terus berkembang dan mengalami dinamika tergantung pada kondisi dan kebijakan setiap negara masing-masing dalam mengadapinya dan menanganinya. Hal tersebut juga sangat ditentukan oleh respon masayarakatnya yang begitu beragam besar kecil jumlah populasinya sersifat relative, yang secara perlahan juga memberi banyak impliksi luasa pada krisis sosial, ekonomi dan keamanan

Pemerintah Indonesia kini telah berupaya melakukan dan merancang berbagai langkah untuk pemulihan yang mempengaruhi pertumbuhan perekonomian nasional. ${ }^{5}$ Pemulihan ekonomi akan bisa berjalan apabila seluruh komponen baik dari pihak swasta maupun BUMN dan masyarakat ikut adil dalam pertumbuhan ekonomi. Hal ini tidak lepas dari strategi tatanan ekonomi yang lebih inovatif dan kreatif sehingga mampu melihat peluang yang memberikan kontribusi yang signifikan pada pertumbuhan dan pembangunan ekonomi.

Pandemi covid 19 telah membawa perubahan dalam sektor ekonomi dan bisnis. Kondisi ini juga berpengaruh pada perubahan pemasaran, ketika pemerintah memberlakukan Pembatasan Sosial Berskla Besar (PSBB) di ibukota DKI Jakarta dan Kota-kota lainnya. ${ }^{6}$ Para pemasar harus mencari cara agar tetap memasarkan produk atau jasa mereka pada konsumen sehingga dapat mempertahankan bisnis di tengah pandemi covid 19. Sebab krisis ekonomi saat ini ikut menurunkan daya beli masyarakat serta menyebabkan perubahan perilaku konsumen. Banyak bisnis mulai mengalami penurunan penjualan secara dratis karena pelanggan memilih beraktivitas di rumah masing-masing. Selain itu, pelaku usaha terutama sektor industri massal yang mulai merumakan, bahkan memberhentikan karyawanya karena pendapatan terus menurun. ${ }^{7}$

Komunikasi Pemasaran dengan model Elektronik Commerce atau perdangangan elektronik merupakan keputusan terbaik bagi pelaku bisnis. ${ }^{8}$ Elektronik Commerce mampu memberikan kemudahan bagi konsumen dalam pencarian informasi terkait kebutuhan dan keinginan mereka secara daring dengan berbagai macam produk atau jasa yang ditawarkan. Dengan demikian, Elektronik Commerce akan dapat membantu pemasar dalam menciptakan strategi penjualan yang efektif melalui pengembangan dan inovasi konsep bauran pemasar yang sesuai kebutuhan di masa pandemi. Tantangan bagi pemasar mengidentifikasi peluang bisnis di masa pandemi dengan mengarahkan fokus kepada pemasar berbasis digital melalui website yang dijadikan elektronik commerce, media sosial, penjualan melalui marketplace bahkan membentuk tim reseller untuk penjual produk.

\footnotetext{
${ }^{4}$ WHO,"Basic protective measures against the newcoronavirus",https://www.who.int/emergencies/ diseases/novel-coronavirus-2019/advice-for-public,diakses14April2020;"Social Distancing, Quarantine, and Isolation", https://www.cdc.gov/coronavirus/2019-ncov/prevent-getting-sick/social-distancing.html,diakses 14 April 2020

${ }^{5}$ https://www.ekon.go.idl, diambil pada tanggal 25 Juli, 2020, Pukul 11.00 WIB

${ }^{6}$ Silfa Hanoatubun, Dampak Covid-19 Terhadap perekonomian Indonesia, Jurnal EduPsyCouns Journal, Vol. 2 No. 1 tahun 2020, ISSN Online 2717-4446

${ }^{7} h t t p: / / w w w . d e p k o p . g o . i d /$, diambil pada tanggal 22 Juli 2020, pukul 19.44 WIB.

${ }^{8}$ Osgar Sahim Matompo, Legal Protection of Online Business Transaction (E-commerce) During the Covid19 Pancemi in Indonesia, Jurnal Ilmu Hukum, vol. 4No. 1 Maret 2020
} 
Riset facebook dan Brain \& Company menunjukan belanja online tetap menjadi tren saat normal baru. ${ }^{9}$ Perusahaan elektronik commerce seperti tokopedia ${ }^{10}$, bukalapak, shopee hingga blibli pun menyiapkan sejumlah strategi untuk merebut pasar. CEO Tokopedia William Tanuwijaya mengatakan perusahaan melihat beberapa kebiasaan msyarakat yang berubah secara permanen saat normal baru, termasuk kebiasaan berbelanja daring. Prioritas utama tokopedia dalam meningkatkan pertumbuhan ekonomi nasional adalah mengaja para pelaku bisnis menjadi mitra di tokopedia, Tokopedia berusaha memastikan masyarakat dapat memenuhi berbagai kebutuhan dari rumah. Tetap manjadi elektronik commerce Indonesia yang dapat di percaya dan dengan memiliki pelayanan terbaik. ${ }^{11}$

Para pelaku bisnis atau penjual baru banyak menjadi mitra tokopedia sehinga terjadi lonjakan penjual di tokopedia. Sehingga hal ini menjadi hal yang positif bagi ecommerce tokopedia di masa pandemic covid-19. Platform e-commerce ini mencatat peningkatan jumlah yang dratis di awal tahun 2020. Tahun lalu seller mencapai 6 juta ditahun 2020 telah mencapai 7,8 juta. Pertumbuhan yang eksponesial ini disebabkan bisnis offline yang terpaksa menutup toko fisik atau membatasi operasionalnya karena pandemic. Akibatnya, sebagai pilihan menjalankan bisnis offline ke online.

Tokopedia selama bulan Maret,terdapat beberapa kategori yang terus meningkat dratis yaitu kesehatan, keperluan rumah tangga serta makanan dan minuman.

Pada bulan juni 2020, pesanan tokopedia paling banyak di kunjungi oleh masyarakat Indonesia dengan total pengunjung kurang lebih $1.2 \mathrm{~m}$, dengan pengunjung 863,1 juta dari web smartphone dan 329,8 melalui deskop.

Perbandingan e-commerce pelaku binis pada setiap platform dapat dilihat ditabel berikut ini:

Nama E-Commerce Jumlah Pengujung Kategori yang diminati

Tokopedia $\quad 1.2 \mathrm{M} \quad$ Kesehatan, Alat Rumah Tangga dan makanan/minuman

Shopee 837,1 juta Pakaian, Kesehatan, Makanan/Minuman

Bukalapak 823,5 Juta Otomotif,Elektronik dan kebutuhan tersier lainya

Dari hal tersebut tentu para elektonik commerce memiliki strategi komunikasi yang sangat berperan penting dan massif agar dapat mencapai keberhasilan masingmasing dalam memberikan pelayanan terbaik kepada konsumennya dengan berbagai diskon dan vocher belanja dan mengajak sebagai strategi komunikasi pesaing bisnis elektronik commerce yang berkembang saat ini. Selanjutnya, ketertarikan fenomena perkembangan elektronik commerce di Indonesia mengantarkan penelitian ini untuk

${ }^{9}$ https://www.tokopedia.com/about/, diambil pada tanggal 27 Juli 2020, pukul 60.00 WIB.

10 Tokopedia, perusahaan teknologi Indonesia, memiliki misi mencapai pemerataan ekonomi secara digital. Visi Tokopedia adalah membangun sebuah Super Ecosystem dimana siapa pun bisa memulai dan menemukan apa pun. Saat ini, Tokopedia memberdayakan jutaan penjual dan pengguna melalui marketplace dan produk digital, fintech dan pembayaran, logistik dan fulfillment, serta Mitra Tokopedia.

${ }^{11}$ Melania Adelia, Implementasi Organisasi yang dinamis di Tokopedia pada era Covid 19, Jurnal SSRN Vol. 3 No. 2 Juni 62020 
mengkaji strategi komunikasi pelaku bisnis electronic commerce di masa pandemi covid-19 studi kasus Mitra tokopedia di Medan. Adapun rumusan masalah yang menjadi penelitian ini adalah sebagai berikut:

\section{B. Metodologi Penelitian}

Metode penelitian merupakan suatu desain penelitian yang utuh, mencakup pendekatan yang digunakan, tehnik pengumpulan data, sampai pada penentuan lokasi penelitian. Adapun jenis penelitian ini adalah kualitatif deskriptif. Pendekatan ini diarahkan pada latar dan individu secara holistik/utuh. ${ }^{12}$ Sebagai informan dalam penelitian ini adalah mitra tokopedia dan pelanggan dengan batasan jumlah sebanyak 5 informan. Adapun sebagai sumber data terdapat data buku-buku pendukung dan jurnal yang membatu dalam landasan teorinya. Teknik pengumpulan data dalam penelitian ini menggunakan metode wawancara secara mendalam, observasi dan dokumentasi.

\section{HASIL DAN PEMBAHASAN}

\section{A. Tokopedia sebagai Start-Up Indonesia}

Pendiri Tokopedia adalah William Tanuwijaya dan Leontinus Alpha Edison. Bermula pada masalah tidak meratanya ekonomi antara kota besar dan kota kecil, serta sebagai Negara kepulauan yang menjadi tantangan paling utama. Maka mereka berpikir untuk menghentikan permasalahan ini. Sehingga pada tanggal 17 Agustus 2009, mereka meluncurkan Tokopedia dengan misi pemerataan ekonomi secara digital.

Awal mula tokopedia tumbuh secara signifikan dan kreatif dari tahun dan beberapa tahun selanjutnya. Sejak awal di luncurkannya tokopedia di tahun 2009 tokopedia memulai bisnis yang di biasa di sebut consumer to consumer (C2C) marketplace, pada tahun 2014 tokopedia menjadi perusahaan Indonesia pertama di portofolio Softbank dan sequoia, pada tahun 2015 tokopedia memelopori instans delivery dengan perusahaan transpotasi online, tahun 2016 tokopedia memasuki bisnis produk digital dan Fintech,

Tahun 2017 tokopedia mendapatkan pendanaan 1.1 miliar dolar dari Alibaba Group, 2018 tokopeid melakukan pertukaran pendanaan baru sebesar 1.1 miliar dolar dari Softbank visioan fund dan alibaba Group, pada tahun 2019 perusahaana ini memperkenalkan tokopedia salam, di tahun 2020 perusahan ini meluncurkan tokopedia jasa. $^{13}$

Bahkan tokopedia mengatahkan dalam blognya untuk decade berikutnya, tokopedia akan fokus pada upaya mengembangkan super ecosystem yang memungkinkan dan memberikan setiap orang dapat berkontribusi dan memberikan nilai tambah bagi satu sama lain serta tumbuh bersama. Tokopedia telah membangun jembatan dengan banyak mitra, termasuk mitra logistic dan pembayaran, dan tokopedia masih terus berupaya membangun jaringan yang lebih kuat.

${ }^{12}$ Moleong, Lexy. J, Metode Penelitian Kualitatif (Bandung: Remaja Rosdakarya 2000), h. 3.

${ }^{13}$ Http://www.tokopedia.com.about dilihat pada tanggal 23 Januari 2021 
Tokopedia memiliki visi untuk "Membangun Indonesia yang lebih baik lewat Internet." Tokopedia mempunyai program untuk mendukung para pelaku Usaha Mikro Kecil dan Menengah (UMKM) dan perorangan untuk mengembangkan usaha mereka dengan memasarkan produk secara online. Tokopedia adalah perusahaan internet yang memungkinkan setiap individu dan pemilik bisnis di Indonesia untuk mengembagkan dan mengelola bisnis online mereka secara mudah dan gratis, sekaligus memungkinkan pengalaman berbelanja online yang lebih aman dan nyaman. Tokopedia percaya bahwa marketplace adalah bisnis modal paling indah di dunia, karena kesuksesan sebuah marketplace hanya dapat di rai dengan membuat orang lain menjadi lebih sukses.

a. Visi Tokopedia

"Membangun Indonesia lebih baik lewat Internet"

b. Misi

Untuk terus berusaha membarikan kesempatan kepada setiap individu di inonesia untuk memulai bisnis dengan mudah dan gratis di Tokopedia. Adapun hal yang perlu diperhatikan adalah sebagai berikut:

1. Selalu positif

Keep positif attitude (selalu membangun dan memelihara sikap positif dan menjauhkan sikap negatif), Build positive teamwork (belajar dan bertumbuh bersama dan memperlakukan rekan kerja seperti keluarga)

2. Memecahkan masalah

Solution oriented (menganalisa ini permasalahan dan kemudian mencari solusi terbaik untuknya), Tink BIG (berfikir jauh ke depan untuk setiap langkah yang di ambil), Set Your Standarda Veery Hig (Jangan mudah puas dan selalu temukan target dan tantangan baru), Accepting challenges, embracing mistakes (menerima tantangan dan belajar dari kesalahan)

3. Menjadi yang terbaik

4. Generasi Indonesia yang lebih baik

Integrity (memelihara sikap jujur dan menjaga integritas yang baik), Character (membangun dan menjaga nilai-nilai karakter diri yang positif)

5. Fokus pada Pelanggan

Build Awesame Product (membangun produk yang bermanfaat), Give best service (selalu memberikan pelayanan yang terbaik) ${ }^{14}$

c. nilai

selalu berpijak di tanah (hamble) seperti pohon

\footnotetext{
${ }^{14}$ https://www.tokopedia.com.about di lihat pada tanggal 23 Januari 2021
} 
pantang meyerah (determination) seperti aliran air

semangat (passion) yang membara seperti api

kecepatan (speed) seperti aingi dan

keberanian (courage) untuk bermimpi mengapai langit

d. $\log 0$

Tokopedia didominasi dengan warna hijau karena warna hijau identi dengan bumi yang menjadi lambing dari kerendahan hati dan ketenangan.tokopedia selalu berusaha untuk tidak egois dan selalu melihat dari sisi pengguna. Banyak fitur-fitur di tokopedia yang berasal dari masukan para toppers (pengguna aplikasi Tokopedia) toped (burung hantu berwarna hijau) adalah "mascot" dari Tokopedia. Logo dari Tokopedia itu sendri adalah tulisan berwarna hijau yang bertuliskan "tokopedia"

\section{e.Maskot}

Toped sebagai mascot dari tokopedia dan burung hantu dijadikan sebagai simbol karena memiliki arti sebagai kecerdasan dan kebijaksanaan, serta burung hantu juga memiliki kemampuna untuk melihat ke semua arah. Begitu pula dengan tokopedia yang selalu berusaha untuk melihat dari berbagai sudut, baik pembeli maupun penjual dalam mengembangkan layanan tokopedia agar bisa semakin memudahkan

\section{f. slogan}

Slogan "sudah cek Tokopedia belum? Menjadi salah satu pemasaran Tokopedia ke public justru sukses membuat orang dengan mudah mengenal dan mengetahui tokopedia. ${ }^{15}$ Slogan ini memiliki latar belakang, yaitu tokopedia selalu menjalin hubungan baik dengan user maupun marchant-nya. Selain itu ytokopedia juga berusaha untuk memberikan pelayanan terbaik untuk user dan marchantnya. Kedektannya ini akhirnya membawa Tokopedia menemukan sloganya. User dan marchant sering ditanya "kalo mau cari barang bagus dan murah dimana ya?" mereka dengan kompak menjawab "udah cek Tokopedia?". Karena banyaknya user dan merchant yang menyampaikan kalimat ini, Tim Management dan Tim Repp akhirnya menjadikan " Sudah cek Tokopedia belum?" sebagai slogan dari Tokepedia. $^{16}$

\section{B. Temuan penelitian}

Dari temuan penelitian, berikut data Pelaku Bisnis yang menjadi informan dalam penelitian ini di e-commerce Tokopedia:

1. Kesehatan

a. Toko : Mahkota 2000

\footnotetext{
15 https://www.tokopedia.com.about dilihat pada tanggal 23 Januari 2021

16 Fadel Reten Lupi dan Nurdin, Analisis Strategi pemasaran dan Penjualan e-commerce pada tokopedia.com, jurnal Elektronik Sistem Informasi dan Komputer, Vol.2 N0.1 Januari-Juni 2016
} 
An-Nadwah, Vol. XXVI, No.1, Januari-Juni 2020

Lokasi : Medan

Followers: 2.14 ribu

Bestseller: Masker Medis

Bebas Ongkir dan Cashback 3\%-80\%

172 Ulasan $(4.8 / 5)^{17}$

2. Perlengkapan Anak Bayi

a. Popok bayi

Nama Toko : Pakanku ${ }^{18}$

Produk yang terjual : popok bayi kain

Lokasi : Medan

Follower: 299

Tahun berdiri: September 2015

Terjual : 132 dengan ulasan 9

Rating : 4.8

Bebas Ongkir dan cashback 5\%-80\%

3. Fasion

a. Nama Toko: ToYou Shop ${ }^{19}$

Lokasi : Medan

Followers: 667

Berdiri : juli 2020

Produk : baju tidur/ piyama cewek

Terjual : 37

Rating toko 4.9 dengan ulasan 7

Bebas ongkir dan cahsback 5 ribu -10 ribu

\section{Makanan}

\footnotetext{
${ }^{17}$ https://www.tokopedia.com/Mahkota2000, Di lihat pada tanggal 3 Desember 2020

${ }_{18} \mathrm{https}$ ://www.tokopedia.com/pakanku, di lihat pada tanggal 4 Desember 2020

19 https://www.tokopedia.com/toyoushop, dilihat pada tanggal 6 Desember 2020
} 
a. Oleh-oleh Medan

Nama Toko: Ikanasinmedan ${ }^{20}$

Lokasi : Medan

Followers: 912

Berdiri : Januari 2016

Produk : ikan asin cumi

Terjual : 12,2 ribu dengan ulasan 101

Rating toko 4.9

Bebas ongkir

Adapun data informan dalam peneliyian ini sebagai Pelanggan Belanja di Tokopedia adalah sebagai berikut:

1. Nama : Anita

Alamat : Jalan Suka Indah Medan Maimun

Pengguna E-Commerce: Tokopedia, Shopee

2. Nama : ibu Juliah

Alamat: Jalan Garu II

Pengguna E-Commerce: Tokopedia, Blibli.com

3. Nama: Abang Ruli

Alamat : Jalan Ismailiyah

Pengguna: Tokopedia

4. Nama: Erwin

Alamat : Jalan Selamet Kataren

Pengguna : Tokopedia

\section{Hasil Temuan}

Pembahasan ini akan mengurai hasil penelitian tentang Strategi komuniaksi pelaku bisnis electronic commerce di masa pandemi covid-19 studi kasus Mitra tokopedia dengan beberapa kategori di antaranya adalah pelaku bisnis yang menjual produk kesehatan, perlengkapan anak bayi, pakaian, alat rumah tangga, elektronik dan kebutuhan

${ }^{20}$ https://www.tokopedia.com/ikanasinmedan, dilihat pada tanggal 18 Desember 2020 
tersier lainnya. Berikut keterangan secara tertulis yang dilakukan pelaku bisnis sebagai trategi di masa pandemic Covid-19.

\section{Kesehatan : masker medis}

Pelaku bisnis yang pertama yaitu dengan nama toko mahkota 2000 buka sejak Desember 2015 yang telah memiliki 2.14 ribu followers, dengan jumlah ulasan 173 terbanyak untuk masker dari 660 yang terjual. Para pembeli memberi respon yang cukup positif kepada toko Mahkota 2000 ini. Pelaku bisnis ini sangat mampu melihat peluang dengan baik, sebab strategi komunikasi yang digunakan dalam mengembangkan produknya sesuai dengan kebutuhan masayarat saat ini yaitu masker. Tokopedia yang dipilih sebagai media yang tidak perlu diragukan lagi dalam pemilihan ecommerce.

Strategi pesan dari pelaku bisnis ini menggunakan ide sesuai minat masyarakat karena saat ini, di era pandemi masyarakat di minta untuk selalu menaati protocol kesehatan, yaitu memakai masker, mencuci tangan dengan memakai sabun yang bersih, menjaga jarak, menjauhi kerumunan, dan membatasi mobilitas dalam berinteraksi. Sehingga, aturan tersebut meningkatkan para pelaku bisnis untuk menjalankan bisnisnya secara online.

Pelaku bisnis saat ini bukan hanya melihat peluang yang ada, namun juga memberikan sebuah kesadaran bahwa dengan belanja online pembeli bisa mendapatkan apa yang dibutuhkan dengan hasil yang juga bagus dan harga terjangkau. Stategi komuniaksi Pelaku bisnis ini juga memberikan bebas ongkir keseluruh Indonesia dan memberikan cashback dari 3\% hingga 80\% sesuai ketentuan yang berlaku.

Secara komunikasi yang di buka dilakukan oleh pelaku bisnis Mahkota 2000 cukup ramah karena past respon saat pembeli bertanya via pesan ataupun komentar di bio produk. Sedangkan untuk jenis electronic commerce yang dijalankan adalah bisnis to consumer (B2C) yaitu pelaku bisnis selaku jasa yang menjual produk kepada konsumen berupa berbagai barang dan kategorinya. ${ }^{21}$

\section{Kelengkapan bayi : popok bayi}

Pelaku bisnis yang ketiga adalah dari kategori perlengkapan bayi, yaitu popok kain, dengan pemilik mitra bisnis adalah pakanku. memiliki pengikut 299, toko ini cukup di percaya oleh konsumen, sebab pembeli memberi ulasan atau komentarnya cukup positif. Sehingga mitra bisnis ini mendapatkan bintang/ rating 4.8 yang cukup di percaya. Bintang yang di dapatkan oleh mitra bisnis di tentukan oleh pembeli, apabila pembeli memberi ulasan yang negatif kepada produknya maka akan mempegaruhi rating yang di dapatkan oleh mitra bisnis.

Orang tua yang memiliki bayi, saat ini mesti pandai memilih tempat belanja online, apalagi mengenai kebutuhan baayi, bayi yang cukup rentan akan radikal

${ }^{21} \mathrm{M}$ Suryanto, Strategi periklanan pada E-Commerce perusahaan top Dunia, (ANDI OFFSET: Yogyakarta, 2002), hal. 10 
bebas membuat orang tua harus mengerti dan memahami hal-hal yang menjadi alergi bagi bayi. Begitu halnya, dengan popok bayi, banyak bayi tidak cocok dengan popok sekali pake, yang membuat kulitnya iritasi, kemerahan dan gak nyaman bagi bayi. Oleh karena itu, pemilihan popok kain sudah tepat untuk membuat bayi merasa nyaman dengan apa yang di gunakan.

Popok kain yang di jual di medan ini, secara online juga cukup tinggi meminatnya. Karena masa covid-19 yang tidak bisa di prediksi hingga sampai kapan akan berakhir, membuat para ibu memilih belanja online sebagai perlengkapan bayi. Popok kain dengan bahan katun dan lembut, dan bisa di gunakan kembali setelah di cuci membuat penjual popok kain yang offline juga harus berahli ke online. Dan di toko pakanku terbukti dengam jumlah konsumen yang tinggi dan mencapai rating yang cukup di percaya kepada pembeli popok kain dengan ulasan 9 dari 132 yang terjual.

Jika di lihat dari ulasan yang ada dengan jumah terjual yang cukup banyak, tenyata pembeli tidak selalu respon balik kepada mitra bisnis, padahal respon balik sangat di butuhkan untuk kenaikan rating bagi mitra bisnis. Selain lupa untuk memberikan ulasan terkadang terlewatkan dengan gambar toko yang lain, sehigga fokusnya tidak pada memberi ulasan namun, melihat-melihat kebutuhan lainnya yang terdapat di e-commerce yang ada di Android.

\section{Fashion : baju tidur}

Dalam bidang fashion dengan nama toko ToYou Shop khususnya perlengkapan wanita, saat ini peminat belanja online adalah pada pakaian yang santai, nyaman dan bahan yang lembut seperti baju daster, piyama dan setelan baju tidur. Dengan memiliki Followers sebanyak 667, toko ini telah memiliki rating yang sangat tinggi, padahal dilihat pada waktu berdirinya belum lama yaitu juli 2020. Dengan waktu yang singkat dalam mengembangkan bisnisnya toko ini memakai strategi yang unik yaitu menampilkan toko dengan sangat menarik untuk di kunjungi pelangganya.

Tampilan dengan foto-foto produk yang benar-benar di siapkan, menjadikan para pelanggan untuk betah berlama-lama di toko tersebut karena tampilan elatase toko yang bagus, dengan jumlah terjual sebanyak 37/pcs pada setiap itemnya, sehingga toko ini di[ercaya dengan rating toko 4.9 dengan ulasan 7 , dalam hal ini para pelanggan tidak suka memberi ulasan pada toko tersebut, disebabkan kadang para pelanggan merasa ribet untuk melanjutkan ulasan yang di minta oleh mesin otomatis.

Toko ini menyediakan dan menawarkan bebas ongkir dan cahsback 5 ribu -10 ribu, tawaran yang sering muncul di toko masing-masing merupakan strategi marketing para pelaku bisnis di market place yang di sedikan ataupun di buat. Yang tersedia biasanya seperti bebas ongkir, chasback dan COD. Hal ini adalah para mitra yang telah bekerja sama dengan tokopedia, pelaku bisnis dan penawar jasa yang ada. Sedangkan strategi yang dibuat seperti promo yang ada pada toko masing-masing seperti dengan mengikuti toko tersebut otomatis mendapat potongan harga dengan Rp.25.000 dengan tanpa syarat. 
Baju tidur kini menjadi trend akibat aktivitas yang lebih banyak di rumah karena pandemi, mengubah para konsumen belanja kebutuhan yang lebih praktis yaitu dengan pesen melalui handphone dan memili market plece yang tersdia di HP, para konsumen dengan cepat mendapatkan apa yang di pilih. Sementara yang produk seperti baju tidur atau piyama kini menjadi produk yang sangat di pemari, jika dulu sebelum masa pandemi para konsumen belanja baru yang formal atau semi formal, justru kini di masa pandemi para konsumen lebih memilih dan belanja baju yang nyaman di pakai di rumah.

Dengan berbagai model dan warna dan motif, sebagai kreasi para penjual yang di minati pasar, menjadikan baju tidur kita tidak hanya di gunakan dirumah saja, namun juga digunakan saat keluar rumah, jalan-jalan atau bahkan untuk undangan dengan model setelan yang sama.

\section{Makanan}

Pelaku bisnis Toko Indomata_Kacamata ini adalah jenis produk makanan. Lokasi di Medan. Toko ini memiliki Followers 1,33 ribu. Toko ini Berdiri Desember 2019. Produk cemilan kue tradisional telah terjual 196, dengan kepercayaan pelanggan Rating toko 4.9. Bebas ongkir dan cahsback $80 \%$. Toko ini cukup baru dan telah banyak pengikut. Oleh sebab itu, produk ini sangat tinggi peminat.

Sama halnya dengan jenis lain namun termasuk juga dalam kategori makanan kering yaitu Oleh-oleh Medan dengan Nama Toko Ikanasinmedan, berlokasi di Medan. Telah memiliki Followers 912. Berdiri sejak januari 2016, produk yang di minati adalah ikan asin cumi, dengan jumlah terjual 12,2 ribu dengan ulasan 101. Pencapain Rating toko 4.9, dnegan tawaran promo bebas ongkir.

Toko yang telah berjalan selama empat tahun ini juga sangat banyak pelanggan. Tenyata oleh-oleh medan sangat di cari dan banyak minatnya melalui oleh belanja online. Adapun olehg-oleh yang bahan kering atau makanan kue dan cemilan. Dua hal yang berbeda namun masuk dalam kategori yang sama, meski keduanya dari toko yang berbeda.

Adapun tanggapan yang diberikan oleh para pelanggan e-commerce yang peneliti temukan adalah sebagai berikut:

Pelanggan yang pertama adalah ibu Anita, beralamat di jalan Suka Indah Medan Maimun. Ibu anita sendiri adalah penguna ecommerce yang bukan hanya satu, diantaranya adalah Tokopedia dan Shopee. ${ }^{22}$ Ibu anita menyatakan bahwa dalam belanja menggunakan e-commerce yang tersedia di androidnya memudahkannya dalam belanja. Dengan profesi beliau yang kerja kantoran. Para pekerja kantoran yang lebih banyak di ruangan lebih memilih belanja online,sebab ibu anita merasa lebih efektif dan cepat saat belanja melalui e-commerce.

\footnotetext{
${ }^{22}$ Wawancara dengan ibu Anita, pada tanggal 12 Januari 2021
} 
Informan yang kedua adalah ibu Juliah, yang beralamat di Garu II. Beliau adalah pengguna E-Commerce Tokopedia dan Blibli.com. beliau menyatakan bahwa lebih sering belanja di Tokopedia karena, barang-barang yang di cari sangat banyak yang ditemukan dengan mudah. Dan keuntungan gratis ongkir membuat orang kini lebih suka belanja online karena tidak perlu menambah dana untuk pengiriman ongkir.

Ibu juliah juga mengatakan bukan termasuk pelanggan belanja di ecommerce saja. Beliau juga masih lebih sering belanja offline. Apalagi yang sifatnya keperluan yang mendadak. Jika belanja online kan ada waktu yang perlu di tunggu sementara saat belanja yang bener-bener hari ini akan di gunakan tentu saya lebih memilih untuk belanja offline. Sedangkan dalam belanja online antara e-commerce Tokopedia dan Blibli.com. ${ }^{23}$ saya lebih suka belanja di Tokopedia. Walaupun keduanya adalah star-up yang berasal dari Indonesia. Ungkap buk juliah. Karna untuk harga lebih terjangkau di Tokopedia, namun untuk di Blibli.com saya suka dengan tawaran alat rumah tangganya dan harganya juga cukup murah. Namun saya tidak mau menangung resiko untuk belanja peralatan rumah tangga melalui online. Karen akan lebih ribet untuk mengembalikan produk nya daripada saat kita belanjanya. Dan itu termasuk masih dalam kelemahan dalam belanja online.

Berbeda dengan Abang Ruli, yang hanya memiliki satu e-commerce di Handphonenya yaitu Tokopedia. Namun beliau sendiri saat ini belum pernah belanja secara online. ${ }^{24}$ Walaupun telah ada di androidnya. Beliau mengatakan bahwa Tokopedia memang ada sejak pertama kali beliau membeli HP baru. Sehingga beliau hanya cek-cek barang dan harga, untuk belanjanya langsung belum pernah.

Saya belum tertarik untuk belanja di Tokopedia, walaupun notifikasinya yang sering tampil setiap harinya tidak mengganggu saya, dan tidak memperngaruhi saya untuk belanja karena saya bukan tipe yang belanja apalagi yang belum ada manfaatnya bagi saya. Ungkap abang Ruli. ${ }^{25}$

Untuk pelanggan yang keempat adalah abang Erwin, beliau tinggal di kota medan sebagai Mahasiswa. Abang Erwin adalah termasuk pengguna e-commerce yaitu Tokopedia. Beliau biasa mengecek buku-buku filsafat dan hukum secara online. Bang Erwin mengatahkan bahwa untuk mencari buku dan untuk membelinya secara online terkadang susah-susah gampang. ${ }^{26}$ Ada judul nya yang tepat namun penulisnya berbeda atau sebaliknya ada penulisnya namun judul bukunya belum sesuai yang di cari.

Jadi menurut saya e-commerce terutama Tokopedia untuk beberapa kategori bisa unggul namun untuk buku-buku khususnya mereka tidak selalu ada stocknya.

\footnotetext{
${ }^{23}$ Wawancara dengan ibu juliah , pada tanggal 1 Januari 2021

${ }^{24}$ Wawancara dengan abag Ruli, pada Tanggal 6 Desember 2020

${ }^{25}$ Wawancara dengan abang Ruli, pada tanggal 20 Desember 2020

${ }^{26}$ Wawancara dengan abang Erwin, pada tanggal 21 Desember 2020
} 
Iya mungkin minat pasar untuk buku-buku juga tidak sebanyak orang belanja seperti fashion dan skincare atau belanja lainnya.

\section{Perspektif Komuniaksi Islam pada pelaku bisnis Tokopedia}

Perkembangan Teknologi kini telah menyebabkan terjadinya perubahan kultur dan tuntutan hidup dalam masyrakat. Kini telah melahirkan pola hubungan yang baru di antranya adlah dunia ekonomi dan bisnis. Salah satu media andalan konsumen dalam berbelanja adalah melalui e-commerce Tokopedia. ${ }^{27}$

Tokopedia kini sangat menguntungkan bagi kedua pihak yaitu bagi konsumen, jasa dan pelaku bisnis. Bagi kosumen waktu belanja menjadi singkat, harga lebih terjankau, dan efesien waktu yang singkat dalam pemilihan barang. Namun dengan perkembangan teknologi yang saat ini terjadi, di lihat dalam hukum Islam (Fiqih Ekonomi) dengan berbagai syarat dan nilai dalam mengatur sistem bertransaksi ekonomi maka diantaranya perlu peneliti paparkan akan kaedah hukum berintransaksi ekonomi dalam islam khususnya dalam bidang perniagaan atau jual beli.

Pemabahsan tentang Tokopedia dalam persfektif fiqih masuk dalam kategori persoalan ijtihady. Apabila dalam realitas sosial pelaku bisni saat ini, yang sudah menjadi media belanja yang tidak dapat di hindari lagi dan telah merupakan salah satu bentuk keperluan kemanusiaan. Dalam konsep Islam segala sesuatu yang berbentu interaksi sesame manusia (Muamalah) pada dasarnya dibolehkan, sejauh tidak ada dalil yang menentukan keharamannya. Dengan demikian, baik pelaku bisnis dan konsumen dalam menjalankan perdaganganya di Tokopedia harus memenuhi rukun dan syarat jual beli yang telah di garskan dalam islam.

Ditinjau dari teknis transaksinya tokopedia adalah media yang di analogikan atau diqisaskan kepada jual beli as-salam yang telah disyariatkan semenjak awal-awal Islam melalui sunah Nabi SAW. Sehingga dalam berinteraksi perlu adanya kesempakatan memberikan hak khiyar (memilih) bagi si pembeli. Apakah akan tetap mengambil yang sudah sampai ketangannya tersebut, atau membatalkan transaksi kalau seandainya barang tersebut tidak sesuai dengan ciri dan jenis sebagaimana yang tertuang dalam market place penjual.

Segala kebebasan dalam melakukan bisnis $^{28}$ oleh manusia tidak lepas dari pertangungjawaban yang harus di berikan atas aktivitas yang dilakukan sesuai dengan apa yang ada dalam Quran surah Al-Mudatsir ayat 38:

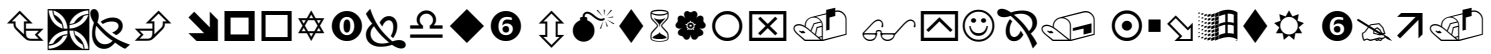

Artinya: tiap-tiap diri bertanggung jawab atas apa yang telah diperbuatnya. ${ }^{29}$

27 Syukri Iska, e-commerce dalam perspektif fikih ekonomi, Jurnal Volume 9 No 2 (Desember 2010)

${ }^{28}$ Staregi komunikasi dalam bisnis adalah panduan cara agar tidak salah dalam membuat sebuah keputusan, sehingga para mitra harus mampu mengatur sesuai target, baik produk yang di promosikan maupun sebuah kepercayaan yang di bangun oleh mitra tokopedia kepada pelangganya. 
Dapat diuraikan bahwa hal muamalah, baik jual beli maupun jasa harus dilakukan berdasarkan etika dan norma-norma agama dan bukan hanya sekedar mengejar keuntungan. Apabila terwujudnya muamalah sesuai yang telah dijelaskan maka kehidupan manusia akan terjalin damai dan dinamis, serta keberuntungan di dunia dan akhirat. Adapun strategi komunikasi yang efektif adalah memanfaatkan sebaik mungkin dalam aktifitas bagi pelaku bisnis, kendati demikian, hambatan yang sering terjadi bagi pelaku bisnis kepada pelangganya tentunya jaringan yang eror, respon yang lama antara kedua bela pihak, barang yang di pesan sudah habis stock dan lain sebagainya.

\section{KESIMPULAN DAN SARAN}

A. Kesimpulan

Berdasarkan penelitian tentang strategi pelaku bisnis eletronic commerce dalam di masa pandemi covid-19 studi kasus tokopedia dengan pengumpulan data baik secara observasi langsung, wawancara dan penelitian dokumen kemudian dilakukan analisis sehingga di tarik beberapa kesimpulan sebagai berikut:

1. Strategi komuniaksi pelaku bisnis Electronic Commerce ( Mitra Tokopedia) dalam pemulihan Ekonomi di masa pandemi Covid 19 sesuai dengan strategi komunikasi yang mana para pelaku bisnis telah menguasai segmen pasar yaitu mampu melihat peluang dan kebutuhan pasar yang di butuhkan saat masa pandemi. Seperti kebutuhan masker, obat-obatan vitamin c, pakaian santai baik pria dan wanita dan kebutuan tersier lainya yang di jual di Tokopedia. Adapun tawaran yang selalu jadi peminat para konsumen adalah gratis ongkir, pembayaran COD, chasback dan sale-sale produk yang mereka jual menjadi strategi yang masif dilakukan oleh pelaku bisnis kepada pelanggan onlinnya..

2. Tantangan pelaku bisnis Electronic Commerce (Tokopedia) dalam menarik konsumen di masa pandemi Covid-19 yaitu persaingan antara para mitra tokopedia yang menjual produk sama namun perbandingan harga yang berbeda, harus mampu aktif dalam mengenalkan tokonya karena hal ini sangat mempengaruhi rating pada toko, semakin sering live akan mengajak para konsumen untuk berkunjung dan belanja. Toko-toko konvensional juga masih menjadi pesaing besar bagi para pelaku bisnis. Sehingga para pelaku bisnis juga bukan hanya jual secara online namun juga offline saat telah memiliki toko sendiri. Hambatan lain bagi pelaku bisnis kepada pelangganya tentunya jaringan yang eror, respon yang lama antara kedua bela pihak, barang yang di pesan sudah habis stock dan lain sebagainya.

3. Perspektif komunikasi Islam pada pelaku bisnis Electronic Commerce (Mitra Tokopedia) adalah persoalan ijitihady. Dalam konsep Islam segala sesuatu interaksi

29 Al-Quran Al-Mudatsir ayat 38, Al-Quran dan Terjemahan Yayasan Penyelengara Penerjemahan/penafsiran al-Quran. Jakarta: Departemen Agama RI. 
sesama manusia pada dasarnya dibolehkan, sejauh tidak ada dalil yang menentukan keharamannya. Ditinjau dari teknis transaksinya tokopedia adalah media yang di analogikan atau diqisaskan kepada jual beli as-salam yang telah disyariatkan semenjak awal-awal Islam melalui sunah Nabi SAW. sehingga dalam berinteraksi perluh adanya kesempakatan memberikan hak khiyar (memilih) bagi si pembeli. Apakah akan tetap mengambil yang sudah sampai ketangannya tersebut, atau membatalkan transaksi kalau seandainya barang tersebut tidak sesuai dengan ciri dan jenis sebagaimana yang tertuang dalam market place penjual.

B. Sara-saran

1. Saran Untuk Pelaku Bisnis

a. Penjualan secara online atau offline harus memahami konsep fiqih ekonomi agar penjualan dapat mendapat keberkahan

b. Tantangan terbesar adalah bertahan dalam berbisnis dan menciptakan inovasi sesuai kebutuhan konsumen agar tidak tinggalkan oleh para pelanggannya

2. Saran untuk Konsumen

a. Belanja sesuai dengan kebutuhan dan mampu memberi manfaat

b. Memanfaatkan sale-sale yang di tawarkan akan mengurangi pengeluaran bulanan

\section{DAFTAR PUSTAKA}

Faisal Badroen, Etika Bisnis Dalam Islam, Jakarta: Prenada Media Group, 2006.

Ismail, Nawari, Metodologi Penelitia, Yogyakarta: Penerbit Samudra Biru, 2015.

Julian Ding, E-Commerce: Law And Office, Malaysia: Sweet AndMaxwel Asia, 1999.

Lexy J Moleong, Metodologi Penelitian Kualitatif, Bandung: Pustaka, 2004

Melania Adelia, Implementasi Organisasi yang dinamis di Tokopedia pada era Covid 19, Jurnal SSRN Vol. 3 No. 2 Juni 62020

M Suryanto, Strategi periklanan pada E-Commerce perusahaan top Dunia, ANDI OFFSET:Yogyakarta, 2002

Niniek Suparni, Cyberspace problematika dan antisipasi pengaturannya. Jakarta: sinar grafika, 2009 